\title{
AKTIVITAS ANTIBAKTERI EKSTRAK DAUN JAHE BALIKPAPAN (ETLINGERA BALIKPAPANENSIS)
}

\author{
Fitri Rhamadhani*, Adam M.Ramadhan, Laode Rijai \\ Laboratorium Penelitian dan Pengembangan FARMAKA TROPIS \\ Fakultas Farmasi Universitas Mulawarman, Samarinda, Kalimantan Timur \\ *email:fitri.r80@gmail.com
}

\begin{abstract}
ABSTRAK
Penelitian ini bertujuan untuk mengidentifikasi senyawa metabolit sekunder serta mengetahui aktivitas antibakteri dari ekstrak daun jahe Balikpapan (Etlingera balikpapanensis) terhadap beberapa bakteri uji. Sampel dikumpulkan dan kemudian dimaserasi menggunakan pelarut metanol. Identifikasi senyawa metabolit sekunder dilakukan menggunakan uji kualitatif dengan mereaksikan sampel dengan beberapa reagen. Pengujian aktivitas antibakteri dilakukan dengan menggunakan metode difusi agar pada konsentrasi 10\%, 20\%, 30\%, 40\% dan 50\%. Data hasil identifikasi metabolit sekunder dianalisis secara deskriptif dengan melihat adanya reaksi positif yang ditimbulkan pada ekstrak. Hasil identifikasi pada ekstrak terdapat senyawa fenolik, steroid dan tanin. Data hasil pengujian antibakteri dianalisis dengan mengukur zona bening yang terbentuk disekitar paper disc. Hasil pengujian antibakteri menunjukkan bahwa ekstrak daun jahe Balikpapan memiliki aktivitas sebagai antibakteri. Konsentrasi efektif ekstrak daun jahe Balikpapan dalam menghambat pertumbuhan bakteri Escherichia coli, Salmonella thypi dan Bacillus subtillis adalah 50\%, sedangkan untuk bakteri Staphylococcus aureus adalah $40 \%$.
\end{abstract}

Kata kunci : Jahe Balikpapan, Etlingera balikpapanensis, antibakteri.

\begin{abstract}
This study aims to identify the secondary metabolites and determine the antibacterial activity of the leaf extract of ginger Balikpapan (Etlingera balikpapanensis) against some bacteria test. Samples were collected and then macerated using methanol. Identification of secondary metabolites was performed using a qualitative test by treating the sample with some reagents. Antibacterial activity test is done by using the agar diffusion method at a concentration of 10\%, 20\%, 30\%, 40\% and 50\%. Data from the identification of secondary metabolites were analyzed descriptively to see their positive reaction generated on the extract. The results of the identification of the extracts are phenolic, steroids and tannins. Antibacterial test data was analyzed by measuring the clear zone formed around the paper disc. Antibacterial test results showed that the leaf extract of ginger Balikpapan has antibacterial activity. The concentration of leaf extract of ginger Balikpapan effective in inhibiting the growth of bacteria Escherichia coli, Salmonella thypi and Bacillus subtillis is $50 \%$, and Staphylococcus aureus is $40 \%$.
\end{abstract}

Keywords: Ginger Balikpapan, Etlingera balikpapanensis, antibacterial. 


\section{PENDAHULUAN}

Salah satu penyakit yang dialami oleh masyarakat yang paling umum adalah infeksi. Infeksi merupakan salah satu penyakit yang disebabkan oleh bakteri. Adapaun bakteribakteri penyebab infeksi diantaranya yaitu Escherichia coli, Salmonella thypi, Bacillus subtillis dan Staphylococcus aureus. Untuk menghambat atau membunuh bakteri-bakteri penyebab infeksi umumnya digunakan obat-obatan antibiotik. Semakin meningkatnya infeksi maka penggunaan antibiotik juga akan semakin meningkat, hal ini dapat menyebabkan besarnya peluang resistensi oleh masyarakat terhadap penggunaan antibiotik. Sehingga dibutuhkan bahan-bahan alam yang dapat membunuh bakteri-bakteri tersebut dengan meminimalisir resistensi maupun efek samping lainnya.

Daun Jahe Balikpapan merupakan salah satu tanaman khas Kalimantan Timur yang ditemukan di Hutan Lindung Sungai Wain, Balikpapan pada tahun 2006 oleh ahli botani yang berasal dari Denmark yaitu Axel Dalberg Poulsen (poulsen). Tanaman ini sangat menarik untuk digali potensinya, dikarenakan belum adanya empiris dan penelitian tentang aktivitas dari tanaman ini. Sehingga dapat dijadikan sebagai alternatif penggunaan bahan alam sebagai obat-obatan salah satunya untuk mengobati infeksi bakteri.

Penelitian ini bertujuan untuk mengidentifikasi senyawa metabolit sekunder serta mengetahui aktivitas antibakteri dari ekstrak daun jahe Balikpapan (Etlingera balikpapanensis) terhadap beberapa bakteri uji, diantaranya yaitu Escherichia coli, Salmonella thypi, Bacillus subtillis dan Staphylococcus aureus.

\section{METODE PENELITIAN Bahan}

Bahan yang diteliti adalah daun jahe Balikpapan (Etlingera balikpapanensis) yang diperoleh dari kawasan konservasi hutan lindung sungai wain Balikpapan. Pelarut yang digunakan pada proses ekstraksi adalah metanol. Mikroba uji yang digunakan adalah Escherchia coli, Salmonella thypi, Bacillus subtilis dan Staphylococcus aureus. Medium yang digunakan adalah Nutrient Agar (NA). $\mathrm{NaCl} 0,9 \%$ sebagai media pensuspensi bakteri. Aquades digunakan untuk melarutkan ekstrak. Paper disc atau kertas saring (Whatman no.42) sebagai penyerap ekstrak untuk uji antimikroba.

\section{Peralatan}

Peralatan yang digunakan dalam penelitian ini antara lain serangkaian alat rotary evaporator, waterbath, cawan porselin, tabung reaksi, rak tabung reaksi, timbangan analitik, cawan petri, LAF (Laminar Air Flow), spoid, inkubator, autoklaf, labu ukur, batang pengaduk, Erlenmeyer, hote plate dan alat penunjang lainnya.

\section{Prosedur Penelitian \\ Pengambilan Sampel}

Daun jahe Balikpapan yang akan digunakan dalam penelitian ini diambil dari tanaman utuh yang kemudian daun tersebut dicuci dengan air mengalir untuk menghilangkan kotoran pada daun. Setelah sampel dicuci dilakukan pemotongan atau perajangan sampel. Dan selanjutnya sampel dikeringkan dengan menggunakan oven pada suhu $55^{\circ} \mathrm{C}$. Kemudian ditimbang berat simplisia kering daun jahe Balikpapan yang telah dihasilkan.

\section{Ekstraksi}

Simplisia daun jahe Balikpapan yang telah diperoleh sebanyak 850 gram diekstraksi menggunakan pelarut metanol dengan metode maserasi selama $2 \times 24$ jam. Ekstrak metanol yang diperoleh kemudian disaring dan dilakukan pemekatan ekstrak menggunakan rotary 
evaporator. Setelah itu diuapkan hingga diperoleh ekstrak kering. Kemudian ditimbang ekstrak kering yang telah diperoleh.

\section{Identifikasi Metabolit Sekunder Uji Alkaloid}

Ekstrak ditambahkan $5 \mathrm{~mL} \mathrm{HCl} \mathrm{2N}$. Larutan kemudian dibagi kedalam tiga tabung reaksi. Tabung 1 ditambahkan 4-5 tetes larutan Dragendorff, tabung 2 ditambahkan 4-5 tetes larutan Mayer dan tabung 3 ditambahkan 4-5 tetes pereaksi Wagner. Reaksi positif bila terbentuk endapan jingga pada tabung 1, reaksi positif bila terbentuk endapan putih pada tabung 2 dan reaksi positif juga dipastikan bila terbentuk endapan coklat pada tabung 3 (Simaremare, 2014).

\section{Uji Flavonoid}

Ekstrak ditambahkan dengan air panas, didihkan selama 5 menit, kemudian disaring. Ditambahkan 0,05 mg serbuk $\mathrm{Mg}$ dan $1 \mathrm{~mL} \mathrm{HCl}$ pekat, kemudian dikocok kuat-kuat. Uji positif ditunjukkan dengan terbentuknya warna merah, kuning atau jingga (Wijaya, 2014).

\section{Uji Fenolik}

Ekstrak ditambahkan dengan $1 \mathrm{~mL}$ larutan Fe(III) klorida 10\%. Jika terbentuk warna biru tua, biru kehitaman atau hitam kehijauan menunjukkan adanya senyawa fenolik (Simaremare, 2014).

\section{Uji Tanin}

Ekstrak ditambahkan dengan $1 \mathrm{~mL}$ larutan Fe(III) klorida 10\%. Jika terbentuk warna biru tua, biru kehitaman atau hitam kehijauan menunjukkan adanya senyawa dan tanin (Simaremare, 2014).

\section{Uji Steroid dan Triterpenoid}

Sebanyak 1 gram ekstrak ditambahkan asam asetat glasial sebanyak 10 tetes dan asams sulfat pekat sebanyak 2 tetes. Larutan dikocok perlahan dan dibiarkan selama beberapa menit. Adanya steroid ditunjukan oleh warna biru atau hijau, sedangkan triterpenoid memberikan warna merah atau ungu (Baud, 2014).

\section{Uji Saponin}

Ekstrak dimasukkan ke dalam tabung reaksi, kemudian ditambahkan air panas lalu didinginkan, kemudian dikocok kuat-kuat selama 10 detik lalu ditambahkan 1 tetes $\mathrm{HCl} 2$ N. Uji positif ditunjukkan dengan terbentuknya buih yang stabil setinggi $1-10 \mathrm{~cm}$ selama tidak kurang dari 10 menit (Baud, 2014)

\section{Pengujian Aktivitas Antibakteri}

Pengujian aktivitas antibakteri dilakukan dengan membuat medium NA terlebih dahulu. Kemudian dilakukan proses sterilisasi alat dan bahan dengan menggunakan autoklaf pada suhu $121^{\circ} \mathrm{C}$ selama 15 menit. Selanjutnya dilakukan pembuatan biakan bakteri dengan menanam bakteri uji diatas permukaan medium NA dengan menggunakan metode agar miring yang telah memadat dalam tabung reaksi, yang kemudian diinkubasi dengan menggunakan inkubator pada suhu $37^{\circ} \mathrm{C}$ selama $1 \times 24$ jam. Setelah diinkubasi dilanjutkan dengan pembuatan suspensi bakteri menggunakan $\mathrm{NaCl}$ 0,9\% hingga diperoleh pengenceran 1:40.

Pengujian aktivitas antibakteri ekstrak daun jahe balikpapan dilakukan dengan metode difusi agar dengan menggunakan medium NA. Sebanyak 0,02 ml suspensi bakteri dengan pengenceran 1:40 dan 10 mL medium NA dimasukkan ke dalam cawan petri steril, kemudian dihomogenkan dan setelah itu ditunggu hingga medium padat. Rendam paperdisc di dalam masing-masing larutan uji dengan berbagai konsentrasi $(10 \%, 20 \%, 30 \%, 40 \%$ dan 50\%) selama 15 menit. Setelah 15 menit diletakkan di atas permukaan medium NA yang telah padat, dan diinkubasi pada suhu $37^{\circ} \mathrm{C}$ selama $1 \times 24$ jam. Kontrol negatif menggunakan paperdisc yang telah dicelupkan di dalam aquades. 


\section{HASIL DAN PEMBAHASAN}

\section{Identifikasi Metabolit Sekunder}

Metabolit sekunder adalah suatu molekul atau produk metabolik yang dihasilkan oleh proses metabolisme sekunder mikroorganisme dimana produk metabolik tersebut bukan merupakan kebutuhan pokok mikroorganisme untuk hidup dan tumbuh. Meskipun tidak dibutuhkan untuk pertumbuhan, namun metabolit sekunder dapat juga berfungsi sebagai nutrisi darurat untuk bertahan hidup (Pratiwi, 2008).

Berdasarkan hasil identifikasi golongan senyawa metabolit sekunder terhadap ekstrak daun Jahe Balikpapan diperoleh hasil bahwa terdeteksinya beberapa golongan senyawa metabolit sekunder, diantaranya yaitu fenolik, tanin dan steroid. Hasil uji metabolit sekunder dapat dilihat pada Tabel 1.

Tabel 1. Data Identifikasi Golongan Senyawa Metabolit Sekunder Daun Jahe Balikpapan

\begin{tabular}{lccccccc} 
& \multicolumn{7}{c}{ Uji Metabolit Sekunder } \\
\cline { 2 - 7 } Sampel & Alkaloid & Flavonoid & Fenolik & Tanin & Steroid & Triterpenoid & Saponin \\
\hline Ekstrak & - & - & + & + & + & - & - \\
Metanol & & - & + & & & & \\
Keterangan: \\
$(+):$ Teridentifikasi metabolit sekunder \\
$(-):$ Tidak teridentifikasi metabolit sekunder
\end{tabular}

\section{Pengujian Aktivitas Antibakteri}

Pengujian aktivitas antibakteri ekstrak daun jahe Balikpapan dilakukan dengan menggunakan 5 (lima) variasi konsentrasi, yaitu 10\%, 20\%, 30\%, 40\% dan 50\% terhadap bakteri Escherichia coli, Salmonella thypi, Bacillus subtillis dan Staphylococcus aureus. Hasil uji aktivitas antibakteri ekstrak daun jahe Balikpapan dapat dilihat pada Gambar 1.
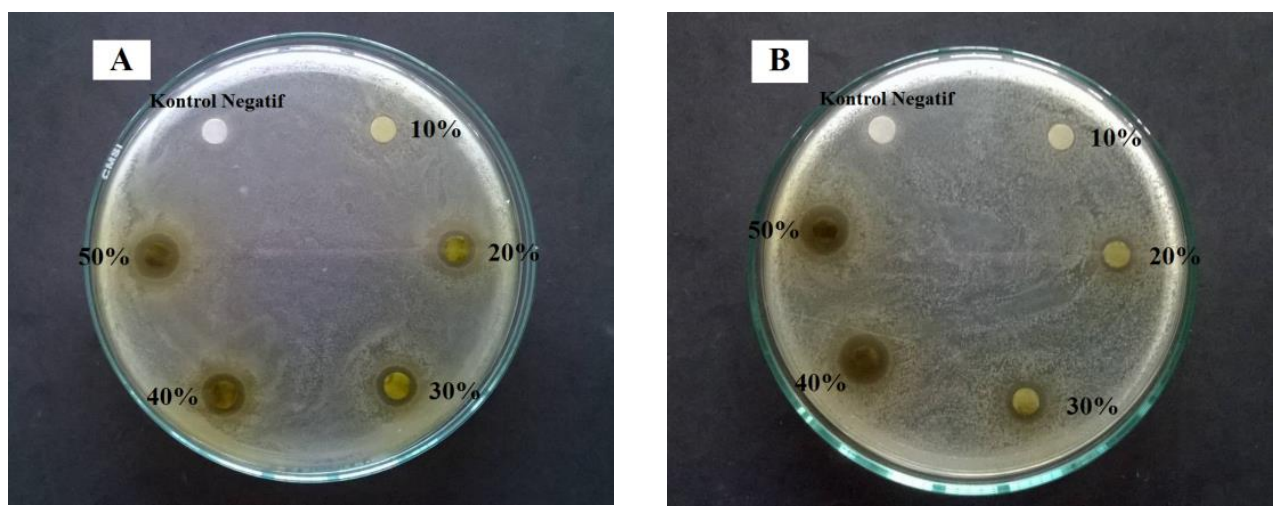

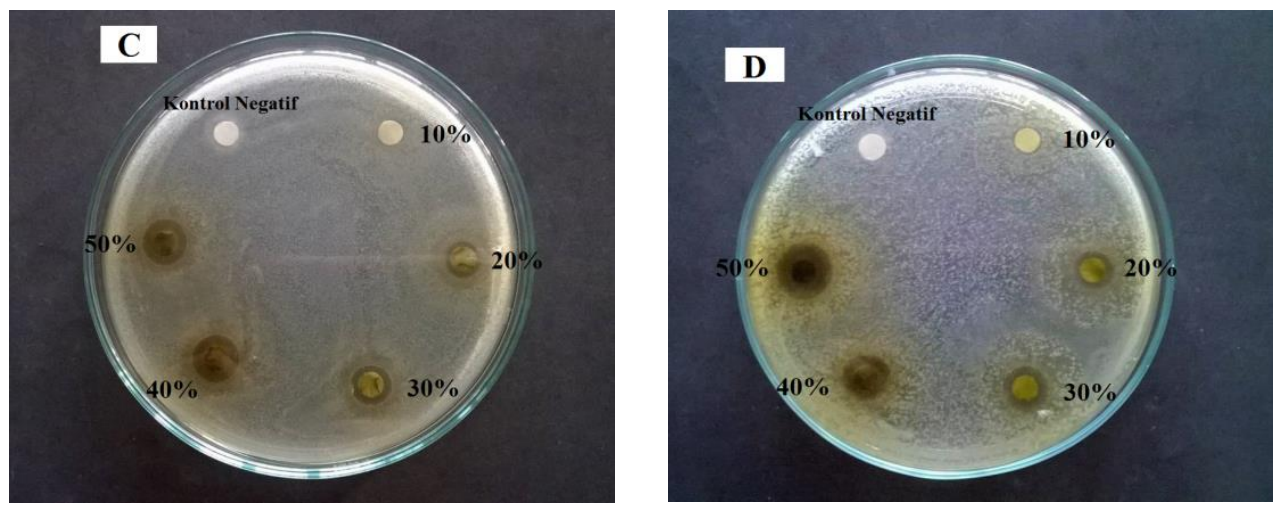

Gambar 1. Uji Aktivitas Antibakteri Ekstrak Daun Jahe Balikpapan Terhadap Bakteri Escherichia coli (A), Salmonella thypi (B), Staphylococcus aureus (C) dan Bacillus subtillis (D)

Berdasarkan hasil pengujian aktivitas antibakteri menunjukkan bahwa ekstrak daun jahe Balikpapan memiliki aktivitas sebagai antibakteri terhadap bakteri Escherichia coli, Salmonella thypi, Bacillus subtillis dan Staphylococcus aureus. Hal ini ditandai dengan terbentuknya zona bunuh disekitar paperdisc. Pada kontrol negatif yang merupakan aquades tidak terbentuk zona bunuh ataupun zona hambat, sehingga dapat diketahui bahwa pelarut yang digunakan tidak mempengaruhi aktivitas antibakteri. Hal ini membuktikan bahwa aktivitas antibakteri yang terbentuk merupakan aktivitas dari ekstrak daun jahe Balikpapan.

Hasil pengujian aktivitas antibakteri ekstrak daun jahe Balikpapan menunjukkan diameter zona bunuh yang berbeda-beda pada tiap konsentrasi terhadap beberapa bakteri seperti yang dapat dilihat pada Tabel 2 .

Tabel 2. Diameter Zona Bunuh Ekstrak Daun Jahe Balikpapan

\begin{tabular}{cccccc}
\hline \multirow{2}{*}{ Sampel } & Konsentrasi & \multicolumn{4}{c}{ Rerata Diameter Zona Bunuh (mm) } \\
\cline { 3 - 6 } & $(\boldsymbol{\%})$ & $\begin{array}{c}\text { Eschericia } \\
\text { coli }\end{array}$ & $\begin{array}{c}\text { Salmonella } \\
\text { thypi }\end{array}$ & $\begin{array}{c}\text { Staphylococcus } \\
\text { aureus }\end{array}$ & $\begin{array}{c}\text { Bacillus } \\
\text { subtillis }\end{array}$ \\
\hline Ekstrak Daun & $10 \%$ & 0 & 0 & 0 & 6.01 \\
Jahe Balikpapan & $20 \%$ & 7.36 & 6.51 & 7.78 & 8.04 \\
(Etlingera & $30 \%$ & 8.06 & 7.38 & 8.1 & 8.13 \\
balikpapanensis) & $40 \%$ & 9.16 & 8.68 & 9.09 & 8.17 \\
Kontrol Negatif & $50 \%$ & 9.5 & 10.03 & 8.49 & 9.76 \\
(Aquades) & 0 & 0 & 0 & 0 & 0 \\
\hline
\end{tabular}




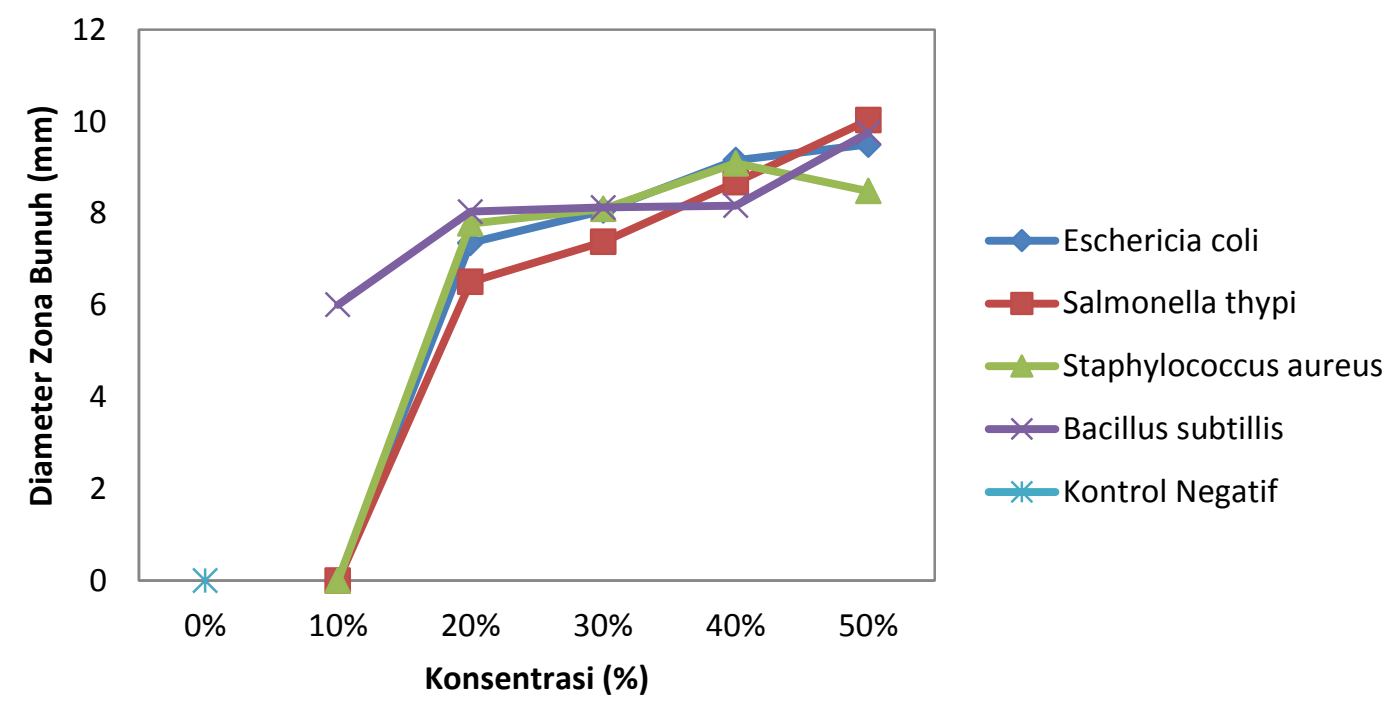

Gambar 2. Grafik Diameter Zona Bunuh Ekstrak Daun Jahe Balikpapan terhadap bakteri Escherichia coli, Salmonella thypi, Staphylococcus aureus dan Bacillus subtillis.

Tabel 1. dan Gambar 2. menunjukkan bahwa terdapat aktivitas antibakteri dari ekstrak daun jahe Balikpapan dengan berbagai konsentrasi terhadap berbagai bakteri. Dimana semakin meningkat konsentrasi ekstrak maka semakin meningkat pula aktivitas sebagai antibakteri. Hal ini ditunjukkan dengan meningkatnya grafik diameter zona bunuh ekstrak daun jahe Balikpapan. Namun apabila konsentrasi ekstrak daun jahe Balikpapan terus ditingkatkan maka dapat terjadi pula penurunan daya bunuh bakteri. Hal ini dimungkinkan karena peningkatan konsentrasi menyebabkan viskositas dari ekstrak semakin meningkat, sehingga dapat mempengaruhi kecepatan difusi ekstrak tersebut dalam media agar. Dapat dilihat pada grafik diameter zona bunuh terhadap bakteri Staphylococcus aureus terjadi penurunan daya hambat pada konsentrasi 50\%, hal ini dimungkinkan karena pada konsentrasi $40 \%$ telah mencapai daya hambat maksimum sehingga pada grafik mengalami penurunan.

Konsentrasi efektif ekstrak daun jahe Balikpapan merupakan konsentrasi yang memberikan aktivitas antibakteri paling besar dalam menghambat atau membunuh pertumbuhan bakteri yang ditunjukkan dengan adanya zona bunuh atau zona hambat.

Gambar 2. menunjukkan bahwa konsentrasi efektif dari ekstrak daun jahe Balikpapan dapat membunuh bakteri Escherichia coli, Salmonella thypi dan Bacillus subtillis adalah 50\%, sedangkan untuk bakteri Staphylococcus aureus adalah $40 \%$.

Aktivitas antibakteri pada ekstrak daun jahe Balikpapan dimungkinkan karena adanya kandungan golongan senyawa metabolit sekunder yang dapat berkhasiat sebagai antibakteri, seperti fenolik dan tanin.

\section{KESIMPULAN}

Berdasarkan penelitian yang telah dilakukan, dapat diperoleh kesimpulan sebagai berikut:

1. Ekstrak daun jahe Balikpapan (Etlingera balikpapanensis) mengandung senyawa golongan metabolit sekunder berupa fenolik, steroid dan tanin.

2. Ekstrak daun jahe Balikpapan (Etlingera balikpapanensis) memiliki aktivitas sebagai antibakteri terhadap bakteri Escherichia coli, Salmonella thypi, Staphylococcus aureus dan Bacillus subtillis. 
3. Konsentrasi efektif ekstrak daun jahe Balikpapan dalam menghambat pertumbuhan bakteri Escherichia coli, Salmonella thypi dan Bacillus subtillis adalah 50\%, sedangkan untuk bakteri Staphylococcus aureus adalah $40 \%$

\section{DAFTAR PUSTAKA}

Baud, Grace S,Meiske S. Sangi. Dan Harry S.J. Koleangan. 2014. Analisis Senyawa Metabolit Sekunder Dan Uji Toksisitas Ekstrak Etanol Batang Tanaman Patah Tulang (Euphorbia tirucalli L.) Dengan Metode Brine Shrimp Lethality Test (BSLT). Jurnal Ilmiah Sains. Vol. 14, No.2.

Poulsen, A. D. 2006. Etlingera Of Borneo. Natural History publications (Borneo).

Pratiwi, Sylvia. 2008. Mikrobiologi Farmasi. EGC. Jakarta.

Simaremare, Eva Susanty. 2014. Skrining Fitokimia Ekstrak Etanol Daun Gatal (Laportea decumana (Roxb.) Wedd). Jurnal Pharmacy. Vol. 11, No.1.

Wijaya, Dwi Putra, Jessy E. Paendong, Jemmy Abidjulu. 2014. Skrining Fitokimia dan Uji Aktivitas Antioksidan dari Daun Nasi (Phrynium capitatum) dengan Metode DPPH (1,1-difenil-2-pikrilhidrazil). Jurnal MIPA UNSRAT Online. 3(1): 11-15 